\title{
PHYSICOCHEMICAL, PHYTOCHEMICAL, BIOLOGICAL AND CHROMATOGRAPHIC EVALUATION OF Saraca Asoca PLANT LEAVES
}

\author{
Samreen Fatema ${ }^{1}$, Mazahar Farooqui ${ }^{2}$, Milind Ubale ${ }^{3}$ \\ and Pathan Mohd Arif ${ }^{1, *}$ \\ ${ }^{1}$ Post Graduate and Research Center, Maulana Azad College, Aurangabad (MS), India 431001. \\ ${ }^{2}$ Dr. Rafiq Zakaria College for Women, Navkhanda, Aurangabad (MS) India 431001. \\ ${ }^{3}$ Vasantrao Naik College, Aurangabad (MS) India 431001. \\ *E--mail: arif7172@ rediffmail.com
}

\begin{abstract}
The main objective of this work is to carry out a physicochemical, phytochemical, biological and chromatographic evaluation of Saraca Asoca. Different physico-chemical parameters, fluorescent test, ash analysis and extractive value of plant leaves have been carried out. The physico-chemical parameters like relative density, viscosity, surface tension and the refractive index of extract solution have been evaluated. Qualitative Phytochemical test has been done for both the extracts. The UV, IR and GC-MS of the extract are also reported. The extracts are tested for antimalarial, anti-tuberclosis and anti-oxidant activity. Ether extract exhibited anti bacterial and anti TB activities.
\end{abstract}

Keywords: Saraca asoca, Extractive value, the biological activity of extracts, phytochemicals.

() RASĀYAN. All rights reserved

\section{INTRODUCTION}

Nowadays, there are various papers appear in which much more emphasis was given on Phytochemical and biological evaluation of plant extract. ${ }^{1-5}$ Few papers also appear in which physicochemical, HPLC, GC-MS study has been reported. They are very important, since plants have been widely used from ancient times for the prevention, cure and treatment of disease particularly in the Indian subcontinent. Ashoka, commonly known as asoca saraca is used for various diseases. It belongs to the Caesalpinaceae family for the present study describes an analytical profile of saraca asoca ${ }^{6}$. Different Plant extracts contain several compounds. For example, from neem oil (Azardirachta indica), nimbin, the first bitter compound is isolated and then more than 135 compounds have been isolated from it. ${ }^{7}$ The search for the biological activity of plant extract is mainly due to three reasons (i) prevalence of disease because of climatic change (ii) search of less expensive and more potent sources of drug and (iii) increased drug resistance power of microbes towards existing drugs. It is the well-known fact that most of the synthetic drugs developed have their beginning in herbal plant extract. ${ }^{8}$

\section{Material and Methods}

\section{EXPERIMENTAL}

All chemicals used for the present investigation were of AnalaR grade from sdfine chemicals Ltd. Double distilled water was used for the preparation of solution as well as aqueous extract. The plant leaves of Saraca asoca was collected from the Maulana Azad College campus. It was dried in shadow and ground to powder, which was extracted immediately using different solvents. The fluorescent tests and ash analysis are carried out. The relative density was calculated by using specific gravity bottle $(10 \mathrm{~mL})$. The viscosity of different solutions was determined using Ostwald's viscometer. Surface tension was

Rasayan J. Chem., 12(2), 616-624(2019)

http://dx.doi.org/10.31788/RJC.2019.1222065

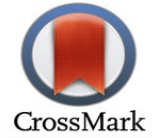


determined using stalagmometer and refractive index by Abbe's refractometer. The qualitative test for phytochemicals such as alkaloids, carbohydrate, proteins, amino acids, phenolic compounds and glycosides has been carried out as described in the literature. ${ }^{9,10}$

UV spectra were obtained on UV double beam spectrophotometer model ELICO 159. The FTIR instrument IRT3000, JASCO, having a serial no. B051061016 used to get IR and spectra were recorded using spectra manager. GC-MS was recorded from Savitribai Phule Pune University, Pune. The biological screening for antibacterial, anti- malarial and anti-tuberculosis activity has been done by disc diffusion method ${ }^{11}$. The anti oxidant activity was determined by the DPPH method. ${ }^{12}$

\section{Fluorescent Test}

\section{RESULTS AND DISCUSSION}

This is a qualitative test and can be used as a preliminary test. When the powder material is treated with acid, base and neutral reagents, it may produce fluorescent light. In the present investigation, fluorescent light is observed in n-butanol, conc. $\mathrm{HCl}$, chloroform and in benzene. Hence in an organic solvent or when conc. $\mathrm{HCl}$ is used the powder produced fluorescence (Table-1)

The various constituents present in the plant material may exhibit a fluorescence phenomenon. UV light produces fluorescence in many compounds and some even in the visible range of day light. By treating with a different chemical reagent, the non fluorescent material can be converted to fluorescent. This is possible because of decomposition of compounds ${ }^{13}$ chromatophores may be produced by chemical treatment.

Table-1: Florescent Test for Leave Powder

\begin{tabular}{c|c|c}
\multicolumn{3}{|c}{ Table-1: Florescent Test for Leave Powder } \\
\hline S. No. & Solution & Observation \\
\hline 1. & Powder $(\mathrm{P})$ as such & Dark green \\
\hline 2. & $\mathrm{P}+$ n-butanol & Florescent green \\
\hline 3. & $\mathrm{P}+$ conc. $\mathrm{HCl}$ & Florescent green \\
\hline 4. & $\mathrm{P}+$ conc. $\mathrm{HNO}_{3}$ & Light yellow \\
\hline 5. & $\mathrm{P}+$ conc. $\mathrm{HSO}_{4}$ & Dark brown \\
\hline 6. & $\mathrm{P}+$ chloroform & Florescent green \\
\hline 7. & $\mathrm{P}+$ ammonia & Reddish yellow \\
\hline 8. & $\mathrm{P}+$ toluene & Yellowish green \\
\hline 9. & $\mathrm{P}+$ glacial acetic acid & Yellow \\
\hline 10 & $\mathrm{P}+1 \mathrm{~N} \mathrm{HCl}$ & No change \\
\hline 11. & $\mathrm{P}+1 \mathrm{~N} \mathrm{NaOH}$ & Reddish yellow \\
\hline 12. & $\mathrm{P}+5 \% \mathrm{HCl}$ & No change \\
\hline 13. & $\mathrm{P}+5 \% \mathrm{NaOH}$ & Reddish green \\
\hline 14. & $\mathrm{P}+$ benzene & Florescent green \\
\hline
\end{tabular}

\section{Ash Analysis}

The total ash content of the sample was found to be $6.6 \%$ out of which the water-soluble ash was $15 \%$ whereas acid insoluble ash was $45 \%$. These values indicate that $6.6 \%$ of inorganic metal acid is present in the sample (Table-2). The acid insoluble ash contains silica material. The plant contains trace quantities of Arsenic (1ppm) and lead (5ppm). ${ }^{14}$

Table-2: Ash Value

\begin{tabular}{c|c|c}
\hline S. No. & Ash & Percentage \\
\hline 1. & Total ash & 6.6 \\
\hline 2. & Water soluble & 15 \\
\hline 3. & Acid-insoluble & 45 \\
\hline
\end{tabular}

\section{Extractive Values}

Different solvents are used for the extraction of plant leaves. The amount extracted is different for different solvents due to various factors. Extractive values of plant leaves depend on: (i.)Types of solvent i.e polar non-polar etc., (ii) Solubility profile of constituents, (iii) Methods of extraction, (iv) species deviations, (v) cultivation season etc. In the present case, plant leaves of some Ashoka tree were extracted 
with different solvents by using the same method in order to avoid the multiple variables. It is observed that more amount gets extracted in water (Table-3).

Table-3: Extractive Values of Saraca asoca Plant Leaves

\begin{tabular}{c|c|c}
\hline S. No. & Extract & Percentage \\
\hline 1. & Water Extract & 21.60 \\
\hline 2. & Diethyl ether Extract & 7.7 \\
\hline
\end{tabular}

The extractive values of flowers of saraca asoca were reported to be highest in water $(22 \% \mathrm{w} / \mathrm{w})$ and lowest in chloroform $(1.8 \% \mathrm{w} / \mathrm{w})$ by earlier research. ${ }^{15}$

\section{Physicochemical Properties}

The physicochemical properties are very much important from an analytical point of view. Since viscosity, density, refractive index, surface tension etc in aqueous solution or any other solvent varies with nature and composition of solutes present in it. There are theories which explain variation in above properties, particularly if a single solute is present in the single solvent, binary solvent, ternary solvents, electrolyte/ non-electrolyte present in the solvent system. In the present case, plant extract is a mixture of several compounds, along with their composition and extract amount is not ascertained, therefore it is difficult to apply any theory to it, but the purpose is to find out co-relation between parameters and concentration so that some base for qualitative estimation can be established. A $30 \mathrm{gm}$ sample powder is extracted $300 \mathrm{~mL}$ of water for 5 hours. The extract is filtered off. The density, viscosity, surface tension and refractive index of the filtrate were determined and recorded in (Table-4). It was then evaporated using rota- evaporator. The solid so obtained was used to prepare $100 \mathrm{ppm}$ solution as a stock solution. This solution is used to prepare various dilutions and their physicochemical parameters were evaluated.

Table-4: Physical Parameters of Solution of Different Concentration

\begin{tabular}{c|c|c|c|c|c}
\hline S. No. & Solution in ppm & $\begin{array}{c}\text { Relative Density } \\
\left(\text { dynes/cm }^{3}\right)\end{array}$ & $\begin{array}{c}\text { Viscosity } \\
(\text { Pascal sec })\end{array}$ & $\begin{array}{c}\text { Surface Tension } \\
(\text { Newton/meter })\end{array}$ & $\begin{array}{c}\text { Refractive } \\
\text { Index }\end{array}$ \\
\hline 1 & 5 & 1.0013 & 0.83694 & 57.4785 & 0.99625 \\
\hline 2 & 10 & 1.0026 & 0.83798 & 47.8930 & 0.99495 \\
\hline 3 & 20 & 0.9968 & 0.79841 & 43.0962 & 1.00063 \\
\hline 4 & 40 & 0.9967 & 0.79830 & 54.0315 & 1.00087 \\
\hline 5 & 60 & 0.9968 & 0.79841 & 49.8846 & 1.00073 \\
\hline 6 & 80 & 0.9956 & 0.83210 & 51.1332 & 1.00199 \\
\hline 7 & 100 & 0.9978 & 0.83393 & 51.2390 & 0.99976 \\
\hline
\end{tabular}

At low concentration, the variation in physical properties is found to be irregular, but at higher concentration, the relative density, viscosity and surface tension increases with increase in concentration. The refractive index shows irregular trends over the entire concentration range, it may be due to nonuniformity of the extract solution. The physic-chemical parameters are most important for the authentication and quality evaluation of commercial plant/herbal drug samples Physic-chemical parameters play an important role and will assist is standardization and ultimately guarantee quality, purity and identification of samples. ${ }^{16}$ There are different physicochemical parameters such as foreign matter, moisture contain, ash analysis, extractive values, foaming index, crude fiber index etc reported for leaves extract in alcoholic extracts of saraca asoca. ${ }^{17}$

\section{Phytochemical Test}

The aqueous extract of saraca asoca shows a positive test for carbohydrate and phenolic compounds etc. the carbohydrates and phenolic compounds were not detected in diethyl ether extract (Table-5). It is reported that the flowers of saraca asoca contain carbohydrate only ${ }^{15}$.

Phytochemical screening, the acetone extract of Ashoka showed the presence of saponin , tannins, and flavonoids which inhibit pyrexia ${ }^{18}$. The study has developed and optimized a convenient high throughput and reliable UPLC-Q-TOF-MS method to analyzed morphologically same parts of s.asoca which can be used for analysis and evaluation of complex herbal medicines ${ }^{19}$. In another study, Divya et al ${ }^{20}$ reported the presence of carbohydrates, flavonoids, saponins, phenols etc in five different solvents. The methanolic 
RASĀYAN J. Chem.

Vol. 12 | No. 2 |616 - 624| April - June | 2019

extract of saraca asoca bark reported to contains a substantial amount of flavonoids and reducing sugar ${ }^{21}$. The alcoholic extract of saraca asoca contains $57 \mathrm{mg}$ of tannin per gram of sample ${ }^{22}$.The flavonoids present in Saraca asoca exhibits preventive action against skin cancer ${ }^{23}$.

Table-5: Qualitative Tests for Saraca acosa Plant Leaves

\begin{tabular}{|c|c|c|c|}
\hline S. No. & Reagent & Water extract & DEE \\
\hline 1. & \multicolumn{3}{|l|}{ Detection of Alkaloids } \\
\hline & Mayer's test & -ve & -ve \\
\hline & Wagner's test & -ve & -ve \\
\hline & Hager's test & +ve & $+\mathrm{ve}$ \\
\hline \multirow[t]{4}{*}{2.} & \multicolumn{3}{|c|}{ Detection of Carbohydrate } \\
\hline & Molisch test & -ve & -ve \\
\hline & Fehling's test & $+\mathrm{ve}$ & -ve \\
\hline & Benedic test & $+\mathrm{ve}$ & -ve \\
\hline \multirow[t]{3}{*}{3.} & \multicolumn{3}{|c|}{ Detection of Proteins and Amino Acid } \\
\hline & Biuret test & -ve & -ve \\
\hline & Ninhydrin Test & -ve & -ve \\
\hline \multirow[t]{5}{*}{4.} & \multicolumn{3}{|c|}{ Detection of Phenolic Compound and Tannins } \\
\hline & Ferric Chloride Test & $+\mathrm{ve}$ & -ve \\
\hline & Gelatin test & -ve & -ve \\
\hline & Lead Acetate Test & $+\mathrm{ve}$ & -ve \\
\hline & Alkaline Reagent Test & $+\mathrm{ve}$ & -ve \\
\hline \multirow[t]{3}{*}{5.} & \multicolumn{3}{|l|}{ Detection of Glycosides } \\
\hline & Borntrager's Test & -ve & -ve \\
\hline & Legal's test & -ve & -ve \\
\hline
\end{tabular}

\section{Spectral Analysis}

The IR spectrum of an extract of saraca asoca was recorded (Fig.-1) Though it contains a mixture of compounds but still in order to find out various functional groups and a general finger print of samples, it will help. The various IR bands observed are represented in Table-6.

Table-6: IR Bands of Saraca asoca Plant Leaves Extract

\begin{tabular}{|c|c|c|}
\hline Band $\left(\mathrm{cm}^{-1}\right)$ & Intensity & Functional group \\
\hline 3347 & Very Broad & $\mathrm{O}-\mathrm{H}, \mathrm{N}-\mathrm{H}$ \\
\hline 2922 & Sharp & Salts of primary amines, cyclic alkane \\
\hline 1603 & Broad & $\mathrm{C}=\mathrm{C}, \mathrm{C}=\mathrm{N}, \mathrm{N}=\mathrm{O}$ \\
\hline 1516 & Sharp & $\mathrm{C}=\mathrm{C}, \mathrm{C}=\mathrm{N}, \mathrm{N}=\mathrm{O}$ \\
\hline 1418 & Broad & $\begin{array}{l}\text { In the compound such as diethyl ketone, in which the } \\
\text { methylene scissoring bond has been shifted to a lower } \\
\text { frequency. }\end{array}$ \\
\hline 1074 & Sharp & $\begin{array}{l}\text { Sec, } \alpha \text {-unsaturated, alicyclic five or six-membered } \\
\text { rings. }\end{array}$ \\
\hline 932 & Sharp & C-O, C-N \\
\hline 818 & Broad & Fermi resonance bending band between $\mathrm{C}=\mathrm{O}$ \\
\hline 770 & Sharp & $\begin{array}{l}\text { The lack of strong absorption bands in } 650 \mathrm{~cm}^{-1} \\
\text { indicates a non-aromatic structure. }\end{array}$ \\
\hline 610 & Very broad & $\begin{array}{l}\text { The lack of strong absorption bands in } 650 \mathrm{~cm}^{-1} \\
\text { indicates a non-aromatic structure. }\end{array}$ \\
\hline
\end{tabular}

The UV spectrum of water extract and diethyl ether extract shows a different pattern (Fig.-2 and 3). Water extract shows $\lambda \max$ at $208 \mathrm{~nm}$ and diethyl ether extract at $257 \mathrm{~nm}$.

\section{Chromatographic Study}

The GC-MS chromatogram was run for 20 minutes. There are eleven peaks observed. The major peaks are at $6.652 \mathrm{~min}, 11.49 \mathrm{~min}$ and $14.99 \mathrm{~min}$ retention time. The expected compounds and presented in Table-7. 
RASĀYAN J. Chem.

Vol. 12 | No. 2 |616 - 624| April - June | 2019

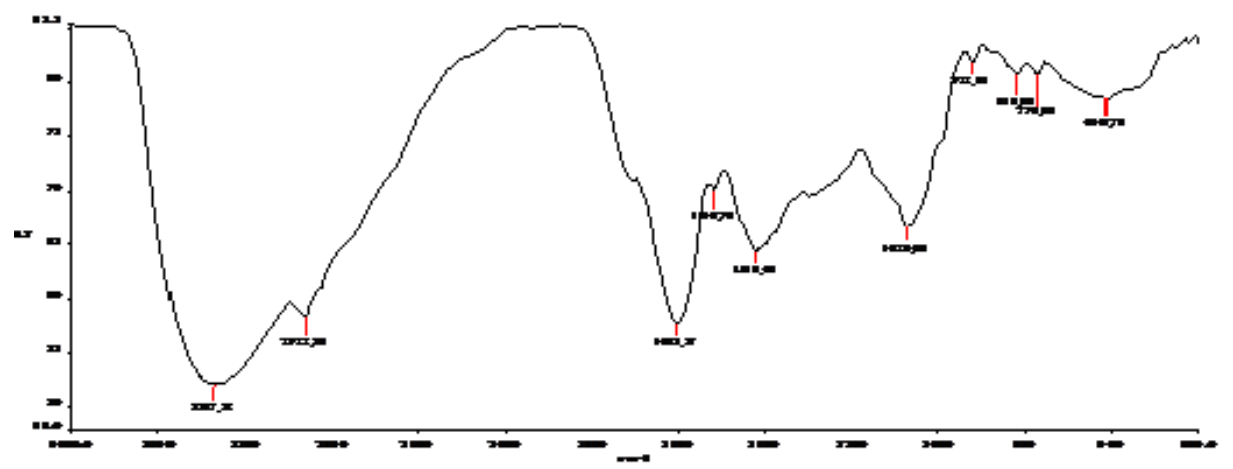

Fig.-1: IR Spectra of Saraca asoca Plant Leaves.

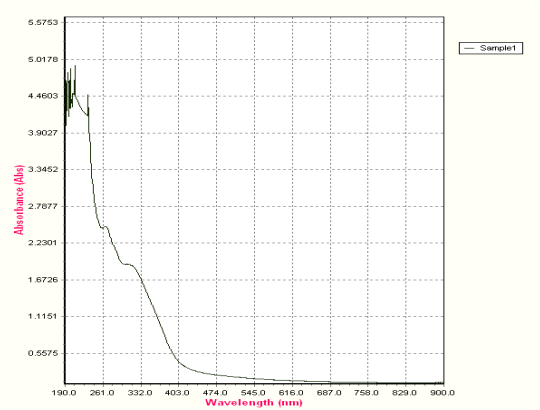

Fig.-2: UV-vis Spectra of Water Extract

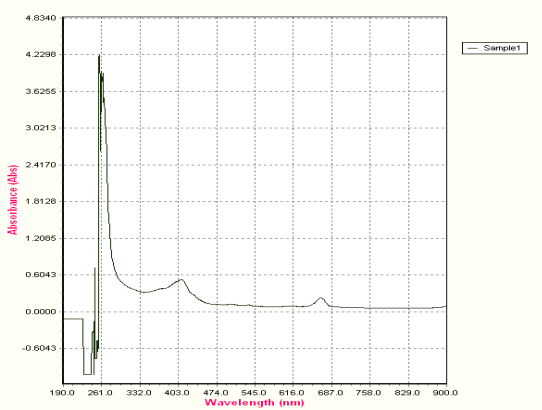

Fig.-3: UV-Vis Spectra of Ether Extract

Table-7: Expected Compounds of Saraca asoca from GC-MS Study

\begin{tabular}{|c|c|c|}
\hline Retention Time & Compounds & Mol. Wt./ Name \\
\hline \multirow[t]{4}{*}{$6.652 \mathrm{~min}$} & & $\begin{array}{c}\text { MF: } \mathrm{C}_{8} \mathrm{H}_{14} \mathrm{O}_{5} \\
\text { MW: } 190 \\
\text { 1,3,2,4-dimethylene-d- } \\
\text { epirhamnitol }\end{array}$ \\
\hline & & $\begin{array}{c}\text { MF: } \mathrm{C}_{7} \mathrm{H}_{15} \mathrm{~N}_{3} \mathrm{O} \\
\text { MW: } 157 \\
\text { 3-(1-piperazimyl)propanamide }\end{array}$ \\
\hline & & $\begin{array}{c}\text { MF: } \mathrm{C}_{8} \mathrm{H}_{16} \mathrm{O}_{2} \\
\text { MW: } 144 \\
\text { 1,4-diethoxy-(2-butene) }\end{array}$ \\
\hline & & $\begin{array}{c}\text { MF: } \mathrm{C}_{8} \mathrm{H}_{12} \mathrm{O}_{4} \\
\text { MW: } 172 \\
\text { 1,3-dimethyl-4,8- } \\
\text { dioxatricyclo[5,1,O,O }(3,5)] \\
\text { octane-2,6-diol }\end{array}$ \\
\hline & & \\
\hline
\end{tabular}


RASĀYAN J. Chem.

Vol. 12 | No. 2 |616 - 624| April - June | 2019

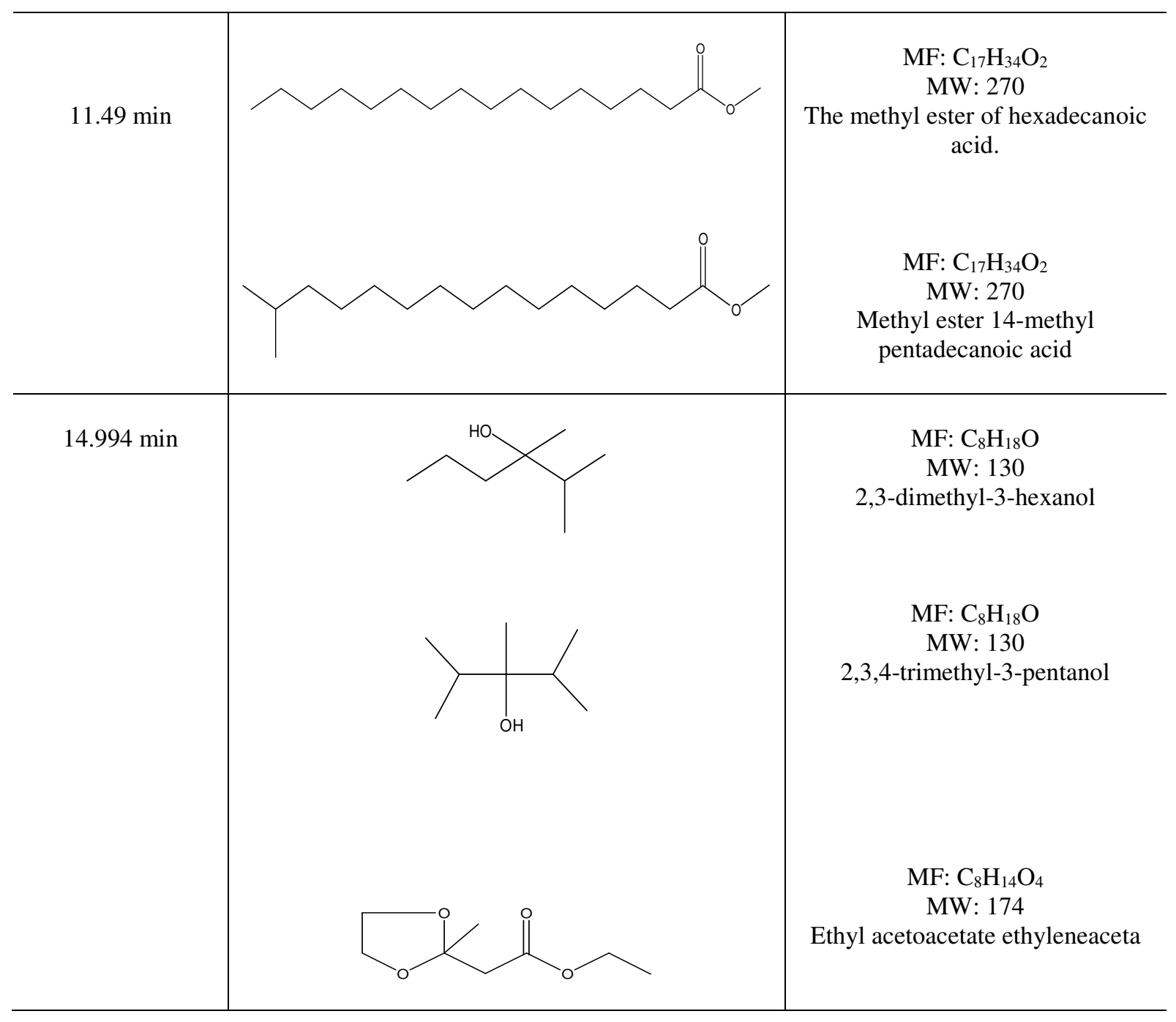

Literature survey revealed that, the hydro distilled oils from the flowers of saraca asoca contains 28 compounds including E,E- $\alpha$-farnesene and methyl salicylate as major components ${ }^{24}$. The leaves of saraca asoca contains number of compounds including catechin, epicatechin, epigallocathechin, galic acid etc. ${ }^{25}$ Saraca asoca contains $0.048 \% \mathrm{w} / \mathrm{w}$ of catechin. It is flavonoids is utilized by naturopaths for the symptomatic treatments of several gastrointestinal respiratory and vascular disease ${ }^{26}$. Saraca asoca bark extract reveal two peaks in HPTLC corresponding to galic acid and epicatechin which results in antismutagenic and antigenotoxic properties of $\operatorname{extact}^{27}$.

\section{Biological Activity}

The ether extract of the Ashoka has been screened for the antibacterial, antituberculosis and antimalarial activity. The extract was found to be active against E.coli, B.Subtilus and S. Aurus but inactive against S. Typhi. It has moderate sensitivity as anti-tuberculosis agent and does not exhibits any anti-malerial activity(Table-8). It is reported that the methanol axtract of saraca indica leaves shows strong in vitro anti-functional activity due to the presence of various phytomedicinal constituents ${ }^{28}$. The methanolic extract also exhibits antibacterial activity against gram positive and gram negative bacteria ${ }^{29}$.The antibacterial properties varies with part of plants, solvent used for the extraction etc. the data obtained in such study leads to the discovery of new drug molecules. A qualitative structure activity relationship can be carried out ${ }^{30}$.

The presence of alkaloids, glycosides, tannins and flavonoids in the ethanolic extract of saraca indica results into antihelmintic activity ${ }^{31}$. Malaria is caused by parasites i.e plasmodium species. It is the most 
common disease of the world and particular in India. The malarial bacteria enter into body through a mosquito bite. There are different medicines available to cure malaria. But day by day drug resistance capacity of bacteria increasing hence some new plant materials with antibacterial activity searched through the world ${ }^{32}$.

Table-8: Biological Activity of leaves of Saraca asoca

\begin{tabular}{c|c|c}
\hline Compound & DEE & Water extract \\
\hline E. Coli & Active & Inactive \\
\hline B. Subtillis & Active & Inactive \\
\hline S. Typhi & Inactive & Active \\
\hline S. Aureus & Active & Inactive \\
\hline Anti TB & Active & Inactive \\
\hline Antimalerial & Inactive & Inactive \\
\hline
\end{tabular}

\section{Anti-oxidant Activity}

The anti-oxidant activity of Ashoka is determined by the DPPH method. These are represented in (Table9 and 10). It is observed that, extracts have less percentage of inhibition compared to standard ascorbic acid, but increases with increase in concentration (Fig.-4). The $\mathrm{IC}_{50}$ value for ether extract was found to be $41.31 \mu \mathrm{g} / \mathrm{ml}$ and for water extract $33.86 \mu \mathrm{g} / \mathrm{ml}$. there are reports that concurrent administration of ethanolic extract of leaves of saraca asoca to albino rats, reducing the lipids alteration and induces antioxidant effect ${ }^{33}$.

Table-9: Anti-oxidant Property of Ascorbic Acid (Standard)

\begin{tabular}{c|c|c|c|c}
\hline S. No. & Concentration, $\mu \mathrm{g} / \mathrm{ml}$ & Absorbance & \% Inhibition & \multirow{2}{*}{$\mathrm{IC}_{50}$ Value, $\mu \mathrm{g} / \mathrm{ml}$} \\
\hline 1 & 5 & 0.491 & 40.48 & \multirow{2}{*}{14.97} \\
\hline 2 & 10 & 0.453 & 45.09 & \multirow{2}{*}{} \\
\hline 3 & 20 & 0.370 & 55.15 & \\
\hline 4 & 30 & 0.335 & 59.39 & \\
\hline 5 & 40 & 0.271 & 67.15 & \\
\hline 6 & 50 & 0.264 & 68.00 & \\
\hline
\end{tabular}

The methanolic extract of the bark of saraca asoca contains lignin glycosides which possess antioxidant potential $^{34}$.Approximately $90 \%$ of age-related disease are linked to activated oxygen ${ }^{35}$. The methanolic extract of Saraca asoca exhibits a high amount of gallic acid, quercetin, ellagic acid in flower and bark, due to which the extract exhibits high antioxidant activity with low $\mathrm{IC}_{50}$ value of $6.8 \mu \mathrm{g} / \mathrm{mL}$ and 6.6 $\mu \mathrm{g} / \mathrm{mL}$ respectively ${ }^{36}$. The main ingredient and two famous ayurvedic formulations 'Ashokarishtam' and 'Asokagritham' is the bark of Ashoka. Thus two formulations are used in treating gyanic and irregular menstruation ${ }^{37}$. Apart from gynecological complications, Saraca asoca is used in the treatment of haemmorhagic dysentery, uterine pain, bacterial infections, cardiac and circulatory problem ${ }^{38}$.

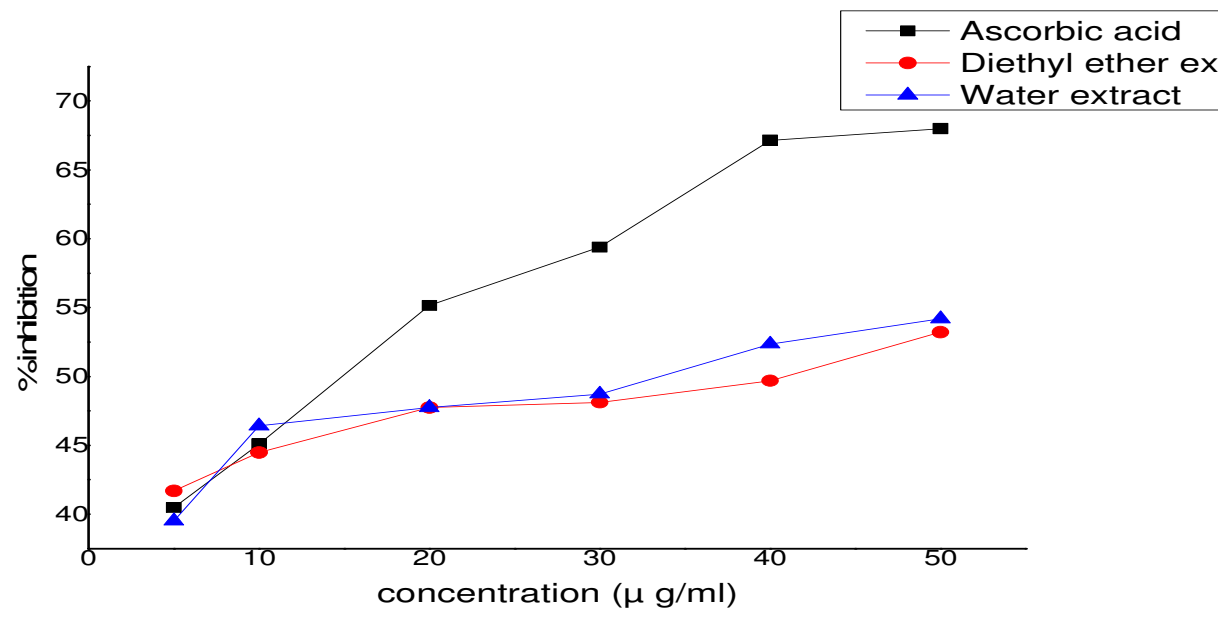


RASĀYAN J. Chem.

Vol. 12 | No. 2 |616 - 624| April - June | 2019

Fig.-4: Anti-oxidant Activity

Table-10: Anti-oxidant Activity of Saraca asoca Leaves Extract

\begin{tabular}{c|c|c|c|c}
\hline Extracts & Concentration, $\mu \mathrm{g} / \mathrm{ml}$ & Absorbance & \% Inhibition & \multirow{2}{*}{$\mathrm{IC}_{50}$ Value, $\mu \mathrm{g} / \mathrm{ml}$} \\
\hline \multirow{4}{*}{$\begin{array}{c}\text { Diethyl } \\
\text { Ether }\end{array}$} & 5 & 0.525 & 41.69 & \multirow{4}{*}{41.31} \\
\cline { 2 - 4 } & 10 & 0.536 & 44.48 & \\
\cline { 2 - 4 } & 20 & 0.544 & 47.75 & \\
\cline { 2 - 4 } & 30 & 0.540 & 48.12 & \multirow{4}{*}{3} \\
\cline { 2 - 4 } & 40 & 0.546 & 49.69 & \multirow{3}{*}{33.86} \\
\cline { 2 - 4 } & 50 & 0.552 & 39.51 & \\
\cline { 2 - 4 } & 5 & 0.532 & 46.42 & \\
\cline { 2 - 4 } & 10 & 0.439 & 47.75 & \\
\cline { 2 - 4 } & 20 & 0.431 & 52.72 & \\
\cline { 2 - 4 } & 30 & 0.385 & 54.18 & \\
\hline
\end{tabular}

\section{CONCLUSION}

In the present study Saraca Asoca leaves were successfully extracted using water and ether solvents. The extracts have shown different colors in solvents. The total ash content is found to be $6.6 \%$ out of which $15 \%$ is water soluble while $45 \%$ acid insoluble. The extractive values in an aqueous medium are $21.6 \%$ and that of diethyl ether $7.7 \%$. The aqueous extract contains alkaloids, carbohydrates, phenolic compound and tannins. GC-MS study is also carried out and library search if also provided for different retention time. Ether extract is comparatively more active as compare to aqueous extract. Ether extract has shown activity against E. Coli, B Subtillis and S Aureus. it also possesses anti Tuberculosis activity.

\section{REFERENCES}

1. Ashvin Godghate, Rajaram Sawant and Ashok Sutar, Rasayan Journal of Chemistry, 5(4), 456( 2012).

2. Samreen Fatema, Mazahar Farooqui, Sunil Jadhav and Pathan Mohd Arif, Indo-American Journal of Pharmaceutical Sciences, 5 (6), 6057 (2018), DOI: 10.5281/zenodo.1304293

3. Dhananjay Dwivedi, Mayuri Thanwar, and A. K. Gharia, Rasayan Journal of Chemistry, 8(4), 522 (2015).

4. Samreen Fatema, Mazahar Farooqui, Ghumre Parmila, Pathan Mohd Arif, Research Journal Of Pharmaceutical, Biological And Chemical Sciences, 9 (3), 603 (2018)

5. Shyam Tulliballi and Ganapaty Seru, Rasayan Journal of Chemistry, 6(2), 102 (2013).

6. Samuel Mathew, Gracy Mathew, P. P. Jay, Baby P. Skaria and T. S. Joseph, Ancient Science of Life, XXIV(4), 174 (2005)

7. S. Susmitha, K. K. Vidyamol, P. Ranganayaki and R. Vijayragavan, Global Journal of Pharmacology, 7(3), 316(2013), DOI: 10.5829/idosi.gjp.2013.7.3.1107

8. Teodora D. Balangcod, Vilma L. Yallejo, Melba Patacsij, Orlando Apostol, Lianne Marie Victoria A. Laruan, Jayjay Manuel, Sonny Cortez and Rosemary M Gutierrez, Indian Journal of Traditional Knowledge, 11(4), 580 (2012). Permila Ghumre, D.B. Jireker, Mazahar Farooqui and S.D. Naikwade, Der Chemica Sinica, 5(4), 65 (2014)

9. Permila Ghumre, D.B. Jireker, Mazahar Farooqui and S.D. Naikwade, International Journal Chemical Science, 12(4), 1221(2014), DOI: 10.21767/0972-768x

10. Permila Ghumre, D.B Jireker, Mazahar Farooqui and S.D. Naikwade, Biosciences Biotechnology Research Asia, 11(3), 2014, DOI: 10.13005/bbra/1578

11. Permila Ghumre, D. B. Jireker, Mazahar Farooqui and S.D. Naikwade, Current Research in Pharmaceutical Sciences, 4(2), 44(2014).

12. M. Suja, Suyambu Rajan, Thiyagrajan Thirunalasundari, Brinda Jana and Sambandan Thenmozhi, Journal of Pharmacy Research, 5(2), 1119 (2012).

13. A. A. Borokar and T. A. Pansare, International journal of Ayurvedic and Herbal Medicine, 7(2), 2524(2017). 
RASĀYAN J. Chem.

Vol. 12 | No. 2 |616 - 624| April - June | 2019

14. Jayita Saha, Taniya Mitra, Kamala Gupta, Sumona Mukherjee, International Journal of Pharmacy and Pharmaceutical Sciences, 4(1), 96 (2012).

15. Sayyada Khatoon, Neha Singh, Santosh Kumar, Journal of Scientific and Industrial Research, 68(5), 393(2009).

16. Pankaj Pradhan, Lincy Joseph, Mathew George, Neha Kaushik, Rahul Chulet, Journal of Pharmacy Research, 3(4), 776 (2010).

17. S. Sasmal, S. Majumadar, M. Gupta, P. K. Mukharjee, Asian Pacific Journal of Tropical Biomedicine, 2(10), 782(2012), DOI: 10.1016/s2221-1691(12)60229-9

18. Anjum Gahlaut, Amey Shirolkar, Vikas Hooda, Rajesh Dabur, Journal of Pharmacy Research, 7(2),143 (2013), DOI: 10.1016/j.jopr.2013.03.005

19. K. R. Divya, A. R. Anjali and T. Rajesh Kumar, Journal of Pharmacognosy and Phytochemistry, 6(3), 518(2017).

20. Manas Kumar Mukhopadhyay, Debjanim Nath, International Journal of Phytomedicine 3, 498 (2011).

21. Vasundhra Saxena, Garima Mishra, Akash Saxena, K. R. Kamlesh, Vishwakarma, Asian Journal of Pharmaceutical and Clinical Research, 6 (3), 148(2013)

22. T. R. Cibin, D. Gayathri Devi and Annie Abraham, Phytotherapy Research, 24(5), 666 (2010), DOI: 10.1002/ptr.2950

23. Rajesh Joshi, Natural Product Research, 30(8), 979 (2016), DOI: 10.1080/14786419.2015.1076818

24. Anjum Gahlaut, Purva Taneja, Amey Shirolkar, Amit Nale, Vikas Hooda and Rajesh Dabur, International Journal of Pharmacy and Pharmaceutical Sciences, 4(4), 331 (2012)

25. Permender Rathee, Sushila Rathee, Deepti Rathee, Dharmender Rathee, Der pharma chemical, 2(1), 306 (2010).

26. Debarati Nag, Manosij Ghosh and Anita Mukharjee, Toxicology and Industrial Health, 31(8), 696 (2013), DOI: $10.1177 / 0748233713483200$

27. Ruhi Tewari, Shankar Kumar Singh, Soumen Choudhury and Satish Kumar Garg, International Journal of Pharmacology, 13 (6), 643 (2017), DOI: 10.3923/ijp.2017.643.648

28. Ch. Mohan, S. Kistamma, P. Vani and A. Narshimha Reddy, International Journal of Current Microbiology and Applied Sciences, 5(3), 300 (2016), DOI: 10.20546/ijcmas.2016.503.036

29. Anjum Gahlout and Anil K. Chhillar, International Journal of Pharmacy and Pharmaceutical Sciences, 5(2), 372 (2013).

30. Nayak Sarojini, Sahoo Anjulata Manjiri, Chakrabarti Chandra Kanti, International Research Journal of Pharmacy, 2(5), 194 (2011)

31. G.A. Ayoola, H.A.B. Coker, S. A. Adesegun, A. A. Adepoju-Bello, K. Obaweya, E.C. Ezennia, T.O. Afangbayila, Journal of Pharmaceutical Research, 7(3), 1019( 2008)

32. Akash Jain, Jasmine, Sunil Sharma, and Vipin Saini, International Journal of Pharmacy and Pharmaceutical Sciences, 5(1), 302 (2013).

33. Samir Kumar Sadhu, Amina Khatun, Panadda Phattanawasin, Takashi Ohtsuki, Masami Ishibashi, J. Nat. Med., DOI: 10.1007/51/418-007-0182-3

34. Rajendra Kshirsagar and Shakti Upadhyay, Natural Product Radiance, 8(2), 117 (2009).

35. Jayita Saha, Sumona Mukherjee, Kanal Gupta, Baskar Gupta, Journal of Pharmacy Research, DOI: 10.1016/j.jopr.(2013).10.004

36. C. Beena and V. V. Radhakrishnan, Annals of Phytomedicine, 1(1), 95 (2012).

37. Satpal Singh, T. H. Anantha Krishna, Subhan Kamalraj, Gini C Kuriacose, Jinn Mathew Valayil and Chelliah Jayabaskaran, Current Science, 109 (10), 1790 (2015), DOI: 10.18520/v109/i10/1790-1801

[RJC-2065/2018] 